\title{
Fermentasi Ampas Sagu (FAS) sebagai Pakan Alternatif Untuk Meningkatan Pertumbuhan Bobot Ayam Kampung
}

\section{Sago Pulp Fermentation as an Alternative feed to Increase Growth in Kampung Chicken Weight}

\author{
Yusuf Suebu $^{1,2}$, Rosye H.R. Tanjung ${ }^{2}$, Suharno ${ }^{2 *}$ \\ ${ }^{1}$ Balai Penelitian Teknologi Pertanian Provinsi Papua \\ ${ }^{2}$ Program Studi Magister Biologi, FMIPA, Universitas Cenderawasih, Jayapura \\ *Email : harn774@yahoo.com
}

Diterima 18 Desember 2019 / Disetujui 28 Januari 2020

\begin{abstract}
ABSTRAK
Sagu (Metroxylon sagu) merupakan tanaman kelompok palm yang mengandung zat pati tinggi, dan telah dimanfaatkan sebagai bahan pangan pokok bagi masyarakat Papua. Semua bagian dari tanaman ini dimanfaatkan untuk kebutuhan manusia. Namun, ampas sebagai bagian dari sisa produk zat pati belum dimanfaatkan. Tujuan dari penelitian ini adalah untuk mengetahui pengaruh fermentasi ampas sagu (FAS) sebagai pakan alternatif untuk pertumbuhan ayam kampung. Penelitian ini dilakukan dengan metode Rancangan Acak Lengkap (RAL) yang terdiri dari 4 perlakuan, yaitu : P0 =Kontrol (PB 100\% dan FAS 0\%), P1 =PB 96\% dan FAS 4\%, P2 =PB 92\% dan FAS 8\%, dan P3 =PB 88\% dan FAS 12\%. Parameter yang diukur antara lain adalah tinggi badan dan bobot ayam. Analisis dilakukan pada ampas sagu baik sebelum fermentasi maupun setelah proses fermentasi. Hasil analisis menunjukkan bahwa FAS mengandung protein kasar, serat kasar, dan lemak kasar mengalami peningkatan masing-masing sebesar 66,5\%,21,1\%,54,5\% dibandingkan sebelum dilakukan fermentasi. Perlakuan FAS tidak memberikan pengaruh terhadap peningkatan tinggi tubuh ayam kampung. Perlakuan signifikan nampak pada parameter bobot tubuh ayam kampung. Peningkatan terbaik bobot ayam terjadi pada perlakuan P1 (PB 96\% dan FAS 4\%). Perlakuan P1 mampu meningkatkan bobot ayam hingga mencapai 17,8\%, sedangkan P2 mencapai 10\%. FAS dapat dimanfaatkan sebagai pakan alternatif dalam meningkatkan pertumbuhan bobot ayam kampung.
\end{abstract}

Kata kunci : sagu, fermentasi, pertumbuhan, ayam kampung

\begin{abstract}
Sago (Metroxylon sago) is included in palm family that contains high starch and has been used as a staple food for Papuan. All parts of this plant are used for human needs. However, pulp as part of the remaining starch product has not been utilized. The purpose of this study was to determine the effect of sago pulp fermentation (FAS) as an alternative feed for the growth of native chickens. The research was conducted with a Completely Randomized Design (CRD) method consisting of 4 treatments, namely: P0 = Control (PB 100\% and FAS 0\%), $\mathrm{P} 1=\mathrm{PB} 96 \%$ and FAS $4 \%, \mathrm{P} 2=\mathrm{PB} 92 \%$ and FAS $8 \%$, and P3 $=$ PB $88 \%$ and FAS $12 \%$. The parameters measured include the height and weight of the chicken. Analysis was carried out on sago pulp both before fermentation and after the fermentation process. The analysis showed that FAS containing crude protein, crude fiber, and crude fat increased by $66.5 \%, 21.1 \%, 54.5 \%$ respectively before fermentation was carried out. FAS treatment did not influence the increase in terms of height of native chicken. Significant treatment was seen in the body weight parameters of native chickens. The best increase in chicken weight occurred in treatment P1 (PB 96\% and FAS 4\%). P1 treatment was able to increase chicken weight to reach 17.8\%, while P2 reached $10 \%$. FAS can be used as an alternative feed in increasing the growth of native chicken weights.
\end{abstract}

Keywords: sago, fermentation, growth, native chicken 


\section{PENDAHULUAN}

Indonesia sebagai negara agraris yang memiliki kawasan hutan luas menjadi salah satu pusat keanekargaman hayati dan sumber pangan. Tanaman sagu (Metroxylon sagu Rottb.) merupakan salah satu tumbuhan khas yang ada di Papua. Tanaman sagu memiliki nilai sosial, ekonomi, budaya (Karim et al., 2008), dan ekologi (Mathur et al., 1998; Karim et al., 2008) yang tinggi. Papua merupakan salah satu pusat keragaman sagu (Ehara et al., 2000; Mubekti, 2013), diperkirakan luas hutan sagu di Indonesia mencapai 1,25 juta (Kusuma et al., 2013), dan sekitar 980.000 ha diantaranya terdapat di Papua. Luas lahan kebun sagu masyarakat diperkirakan sekitar 14.000 ha (Widjono et al., 2000), yang tersebar di beberapa daerah di Papua dan Papua Barat. Semua bagian (organ) dari tanaman sagu dapat dimanfaatkan (Karim et al., 2008). Nilai penting sagu berawal dari bagian zat pati yang dimanfaatkan oleh masyarakat yang diolah secara sederhana (Achmad et al., 1999), namun saat ini telah berkembang hingga pada dunia industri (Flach \& Schuiling, 1989).

Bagi masyarakat Papua, sagu merupakan sumber pangan lokal yang sering diolah menjadi makanan tradisional yaitu "papeda". Selain papeda, sagu dapat diolah menjadi berbagai macam bahan baku pembuatan kue dan industri rumah tangga. Dalam proses pengolahan tanaman sagu menjadi tepung sagudi sentra-sentra produksi, dihasilkan ampas sagu yang cukup tinggi dan pada umumnya hanya dibiarkan menumpuk di sekitar pengolahan sagu. Apabila hal ini dibiarkan akan menimbulkan pencemaran lingkungan. Kompiang et al., 1995). Beberapa faktor penyebab belum dimanfaatkannya ampas sagu oleh petani antara lain, karena petani belum memahami teknologi pengelolaannya, baik sebagai pupuk organik maupun sebagai pakan alternatif bagi ternak.

Ampas sagu memiliki potensi besar untuk dimanfaatkan sebagai pakan ternak ruminansia dan unggas. Menurut Lay \& Patrik (2010), pada suatu proses pengolahan sagu, dihasilkan limbah berupa kulit batang sekitar 17-25\% dan ampas sagu sebanyak 75-83 \%. Ampas sagu dapat dimanfaatkan sebagai campuran substrat biogas karena banyak mengandung bahan organik terutama unsur karbon dan pakan ternak bila diolah dengan baik.

Ampas sagu mengandung 65,7\% pati, 14,8\% serat kasar, $1,0 \%$ protein kasar, dan $4,1 \%$ abu (McDonald et al. (1982). Namun penggunaannya sebagai pakan ternak tidak dapat diberikan secara langsung karena memiliki kandungan serat kasar yang tinggi yaitu sekitar 12-20\% dan protein kasar rendah yaitu $0,1-3,1 \%$ (Usman \& Tirajoh, 2018). Kondisi ini menyebabkan penggunaannya dalam ransum menjadi sangat terbatas. Oleh karena itu, pemanfaatan ampas sagu sebagai pakan ternak unggas sangat diperlukan dengan sentuhan teknologi untuk meningkatkan kandungan nutrisinya. Salah satunya adalah teknologi biofermentasi menggunakan probion. Proses fermentasi menyebabkan perubahan-perubahan yang menguntungkan baik dari aspek gizi maupun daya cernanya serta meningkatkan daya simpanannya (Buckle et al, 1987). Tujuan penelitian ini adalah untuk mengetahui pengaruh fermentasi ampas sagu (FAS) terhadap pertumbuhan ternak ayam kampung.

\section{METODE PENELITIAN}

\section{Lokasi dan Waktu Penelitian}

Penelitian ini dilakukan di kompleks Balai Pengkajian Teknologi Pertanian (BPTP) Papua di Sentani, Jayapura. Percobaan perlakuan FAS dilakukan pada bulan Maret sampai Mei 2019.

\section{Bahan Penelitian}

Penelitian ini mengunakan FAS yang dibuat dengan bantuan formula yang berasal dari ampas sagu dengan pemberian probion dan urea. Ampas sagu yang digunakan berasal dari Kampung Maribu, di Distrik Sentani, Kabupaten Jayapura. Sebanyak 60 ekor bibit ayam kampung berkelamin jantan umur 1 bulan diperoleh dari peternak ayam kampung di daerah Sentani (Kabupaten Jayapura), Arso (Kabupaten Keerom), dan Sarmi (Kabupten Sarmi). Ketiga lokasi tersebut merupakan beberapa tempat sebagai sentra penghasil ayam kampung. 


\section{Perlakuan Penelitian}

Ampas sagu yang dimanfaatkan sebagai bahan pakan dalam ransum ternak ayam kampung adalah ampas sagu yang telah difermentasi. FAS bertujuan untuk meningkatkan kandungan gizi ampas sagu. Formulasi FAS dibuat menggunakan ampas sagu kering yang sudah dibersihkan sebanyak $100 \mathrm{~kg}$, probion $300 \mathrm{~g}$, dan urea $300 \mathrm{~g}$. Ketiga bahan tersebut dicampur secara merata menggunakan air secukupnya atau sekitar 10-20\%. Proses FAS dilakukan selama kurang lebih 15 hari dan dilakukan secara terbuka namun terlindung dari sinar matahari dan air hujan.

Penggunaan fermentasi ampas sagu dalam ransum pakan dicampur dengan pakan basal (PB). PB merupakan campuran pakan pabrik $60 \%$ dan jagung giling $40 \%$. Penelitian ini dirancang dengan menggunakan Rancangan Acak Lengkap (RAL) yang terdiri dari 4 perlakuan ransum dan masingmasing perlakuan terdiri atas 15 ulangan, sehingga terdapat 60 unit percobaan. Perlakuan tersebut adalah: P0 =Kontrol (PB 100\% dan FAS 0\%), P1 $=\mathrm{PB} 96 \%$ dan FAS 4\%, P2 =PB 92\% dan FAS $8 \%$, dan P3 =PB 88\% dan FAS $12 \%$.

Metode pemeliharaan ayam dilakukan dengan sistem satu kandang satu ayam. Kandang dibuat dengan ukuran $60 \times 40 \times 40 \mathrm{~cm}$., yang diberi fasilitas tempat makan dan minum. Pemberian ransum FAS dilakukan berdasarkan atas berat bobot ayam, sehingga perlu ditimbang (Tabel 1). Pemberian pakan dilakukan dua kali setiap hari yaitu pada waktu pagi (07.00-08.00) dan sore (15.00-16.00).

Tabel 1. Takaran pemberian ransum.

\begin{tabular}{ccc}
\hline Minggu & $\begin{array}{c}\text { Pemberian Ransum } \\
\text { (g/ekor) }\end{array}$ & $\begin{array}{c}\text { Rata-Rata } \\
\text { (g/ekor) }\end{array}$ \\
\hline I & $21-28$ & 24.50 \\
II & $29-36$ & 32.50 \\
III & $37-44$ & 40.50 \\
IV & $45-52$ & 48.50 \\
V & $53-60$ & 56.50 \\
VI & $61-68$ & 64.50 \\
VII & $69-76$ & 72.50 \\
VIII & $77-84$ & 80.50 \\
IX & $85-92$ & 88.50 \\
X & $93-100$ & 96.50 \\
\hline
\end{tabular}

\section{Analisis Data}

Data hasil pengamatan dianalisis dengan uji statistik menggunakan program SPSS. Untuk mengetahui pengaruh pemberian FAS terhadap pertumbuhan ayam kampung digunakan Analysis of variance (Anova), dan apabila diketahui terdapat perbedaan signifikan dilanjutkan uji LSD pada tingkat kepercayaaan 95\%.

\section{HASIL DAN PEMBAHASAN}

\section{Karakteristik Fermentasi Ampas Sagu}

Hasil analisis kimia ampas sagu menunjukkan bahwa kandungan gizi ampas sagu sebelum dan setelah fermentasi terjadi perubahan nilai nutrisi (Tabel 2). Kandungan protein kasar, serat kasar, dan lemak kasar sebelum fermentasi masing-masing adalah $1,73 \%, 12,54 \%$ dan $0,11 \%$ dan setelah fermentasi mengalami peningkatan masing-masing sebesar 2,88\%, 15,19\% dan 0,17\%. Menurut Ganjar (1977) bahwa konsentrasi inokulum berpengaruh terhadap proses fermentasi. Inokulum mengandung fungi (spora) yang pada pertumbuhannya menghasilkan enzim yang dapat menguraikan subtrat menjadi komponen yang lebih sederhana. Semakin lama waktu fermentasi yang diberikan semakin banyak bahan yang dapat dirombak menjadi masa sel. Masa sel merupakan protein sel tunggal, sehingga pada akhir fermentasi berpengaruh terhadap kandungan protein kasar yang menjadi meningkat (Sulaiman, 1988). 
Perlakuan fermentasi secara biologi menguntungkan mikroorganisme karena dapat menghasilkan beberapa asam amino. Produk fermentasi lebih mudah dicerna dibandingkan dengan bahan asalnya karena mikrobia mampu menghasilkan berbagai jenis enzim (Nuraini 2006). Beberapa enzim yang dapat dihasilkan mikroorganisme antara lain adalah amilase (Heinz at al., 2005), selulase (Romeo, 1999), protease (Rhodes et al., 1983) dan kitinase (McNab \& Glover, 1991). Selanjutnya, hasil fermentasi dapat berupa asam amino seperti tirosin (Lerch, 1978), arginin (Palmier, 1999), metionin (Marathe et al., 1998), glutamat (Wolf \& Weiss, 1980) dan triptofan (Tsai \& Suskind, 1972).

Tabel 2. Kandungan gizi ampas sagu sebelum dan setelah dilakukan proses fermentasi.

\begin{tabular}{lcc}
\hline Sifat kimia-fisika ampas sagu & Sebelum fermentasi & Setelah fermentasi \\
\hline Kadar air (\%) & 16,64 & 13,60 \\
Protein kasar (\%) & 1,73 & 2,88 \\
Serat kasar (\%) & 12,54 & 15,19 \\
Lemak kasar (\%) & 0,11 & 0,17 \\
Karbohidrat (pati) (\%) & 58,14 & 52,97 \\
\hline
\end{tabular}

Produk fermentasi mempunyai nilai gizi yang lebih baik dari bahan asalnya karena telah mengalami perubahan-perubahan yang menguntungkan seperti dihasilkan flavor, vitamindan asam amino serta dapat meningkatkan daya cerna (Fardiaz, 2002; Pamungkas, 2011). Proses fermentasi dapat memberikan perubahan fisik dan kimia yang menguntungkan seperti aroma, rasa, tekstur, dan daya cerna lebih baik dari bahan asalnya (Pamungkas, 2011).

\section{Pengaruh Pakan Fermentasi Ampas Sagu (FAS) terhadap Tinggi Ayam Kampung}

Hasil pengamatan menunjukkan bahwa FAS tidak berpengaruh nyata terhadap peningkatan tinggi tubuh ayam kampung. Namun, nampak bahwa perlakuan P1 menunjukkan tinggi tubuh tertinggi dibandingkan dengan perlakuan lain dari minggu ke-1 hingga ke-5. Setelah minggu ke-5 pertumbuhan tinggi tubuh ayam kampung relatif sama. Selisih tinggi tubuh antar perlakuan, termasuk kontrol tidak menunjukkan pengaruh signifikan walaupun secara umum mempunyai kecenderungan lebih tinggi.

Tabel 3. Rerata tinggi badan ayam kampung yang diberi perlakuan FAS.

\begin{tabular}{|c|c|c|c|c|c|c|c|c|c|c|c|}
\hline \multirow{2}{*}{ Perlakuan } & \multicolumn{10}{|c|}{$\begin{array}{c}\text { Waktu } \\
\text { (minggu) }\end{array}$} & \multirow[t]{2}{*}{ Rerata } \\
\hline & 1 & 2 & 3 & 4 & 5 & 6 & 7 & 8 & 9 & 10 & \\
\hline P0 & 18,5 & 19,7 & 20,3 & 20,9 & 22,1 & 22,9 & 23,5 & 24,1 & 24,5 & 25,1 & 22,2 \\
\hline P1 & 18,7 & 20,0 & 20,7 & 21,4 & 22,7 & 23,2 & 23,8 & 24,5 & 25,1 & 25,5 & 22,6 \\
\hline $\mathrm{P} 2$ & 18,0 & 19,1 & 20,4 & 21,1 & 22,1 & 23,3 & 23,7 & 24,5 & 25,2 & 25,5 & 22,3 \\
\hline P3 & 18,3 & 19,5 & 20,3 & 21,1 & 22,0 & 23,1 & 23,6 & 24,3 & 24,8 & 25,4 & 22,2 \\
\hline
\end{tabular}

Ket.: P0= Pakan basal (tanpa FAS) 0\%., P1= Pakan basal + FAS 4\%, P2 = Pakan basal + FAS 8\%, P3= Pakan basal + FAS $12 \%$.

\section{Pengaruh Pakan Fermentasi Ampas Sagu (FAS) terhadap Bobot Ayam Kampung}

Berdasarkan hasil penelitian (Gambar 1; Tabel 3) menunjukkan bahwa pertambahan bobot tubuh tertinggi pada ternak ayam kampung periode pertumbuhan diperoleh pada perlakuan P1 yaitu pemberian FAS 4\% sebesar 142,9 g/ekor/minggu, kemudian diikuti oleh perlakuan P2 yaitu pemberian FAS $8 \%$ sebesar 129,1 g/minggu, P0 yaitu pemberian FAS 0\% sebesar 117,4 g/minggu, dan terendah perlakuan P3 yaitu pemberian FAS 
12\%. Hasil analisis statistik terhadap pertambahan bobot badan pada ternak ayam kampung periode pertumbuhan menunjukkan bahwa terjadi perbedaan nyata antar perlakuan $(p<0,05)$. Hasil uji LSD menunjukkan bahwa antara perlakuan P1
(FAS 4\%) memberikan hasil yang berbeda nyata dengan perlakuan P0 (FAS 0\%) dan P3 (ASF 12\%), tetapi tidak berbeda nyata dengan perlakuan $\mathrm{P} 2$ (FAS 8\%). Namun perlakuan antara P0 dengan P2 dan P3 memberikan hasil yang tidak berbeda nyata.

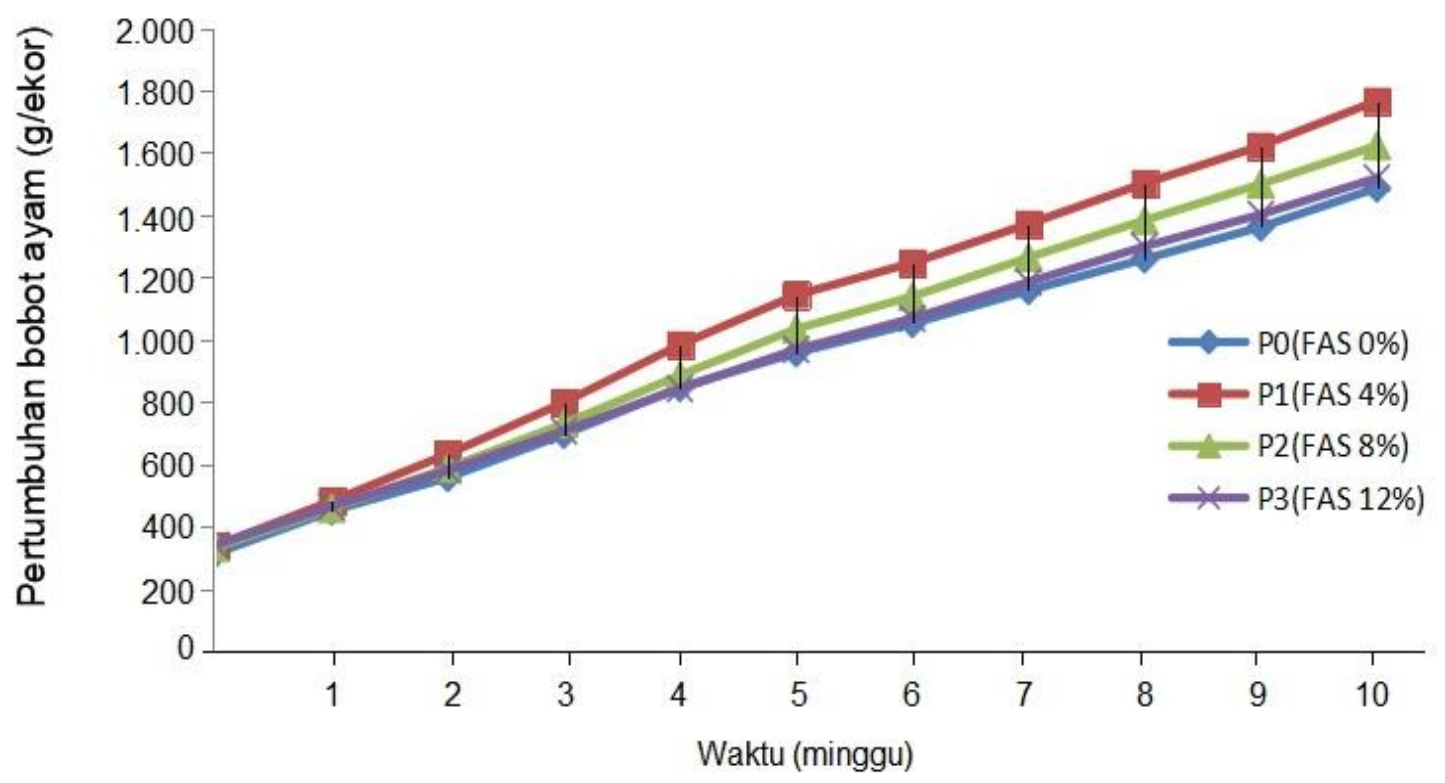

Gambar 1. Grafik pertumbuhan bobot ayam kampung jantan yang diberi perlakuan FAS.

Tabel 3. Rerata pertambahan bobot ayam kampung yang diberi perlakuan FAS.

\begin{tabular}{cccccccccccc}
\hline Perlaku & \multicolumn{10}{c}{ Waktu (minggu) } & \\
\cline { 2 - 12 } an & 1 & 2 & 3 & 4 & 5 & 6 & 7 & 8 & 9 & 10 & Rerata \\
\hline P0 & 136,7 & 107,0 & 139,0 & 150,3 & 111,7 & 94,3 & 105,7 & 101,7 & 102,3 & 125,3 & $117,4^{\mathrm{b}}$ \\
P1 & 143,7 & 151,0 & 165,7 & 185,7 & 159,7 & 103,3 & 125,0 & 130,7 & 119,7 & 144,7 & $142,9^{\text {a }}$ \\
P2 & 125,7 & 130,0 & 142,0 & 155,7 & 149,0 & 104,0 & 125,3 & 119,7 & 116,0 & 123,3 & $129,1^{\text {ab }}$ \\
P3 & 124,3 & 116,3 & 126,3 & 135,7 & 125,7 & 100,0 & 116,7 & 114,3 & 100,7 & 111,0 & $117,1^{\text {b }}$ \\
\hline
\end{tabular}

Ket.: Huruf yang sama pada kolom yang berbeda tidak berbeda nyata $(\mathrm{P}<0,05), \mathrm{P} 0=$ Pakan basal (tanpa FAS) $0 \%$, $\mathrm{P} 1=$ Pakan basal + FAS 4\%, P2 = Pakan basal + FAS 8\%, P3= Pakan basal + FAS 12\%.

Hasil penelitian ini menunjukkan bahwa pemanfaatan fermentasi ampas sagu $4 \%$ sebagai ransum ternak ayam kampung dapat meningkatkan pertambahan bobot badan ayam kampung periode pertumbuhan yang lebih baik dibandingkan dengan perlakuan lainnya. Pengaruh FAS mampu meningkatkan bobot ayam kampung hingga mencapai $17,8 \%$ pada perlakuan P1, sedangkan perlakuan P2 menunjukkan peningkatan lebih kecil, yakni 10,0\% dan P3 tidak mengalami peningkatan $(0,0 \%)$. Kondisi tersebut menunjukkan bahwa semakin tinggi penambahan FAS akan menurunkan persentase peningkatan bobot ayam kampung.
Pemanfaatan FAS dengan perlakuan P1 menunjukkan tingginya pertambahan bobot ayam kampung jantan. Kondisi ini memberikan harapan baru bagi peternak ayam dalam memanfaatkan FAS sebagai alternatif pakan ternak. Menurut Leeson \& Summer (1997) dan Wahyu (1997) peningkatan dan penurunan pertambahan bobot ternak ayam kampung dapat disebabkan oleh beberapa faktor. Faktor tersebut antara lain adalah tingkat konsumsi ransum, kualitas ransum, faktor genetis dan faktor lingkungan. Jumlah ransum yang dikonsumsi akan menentukan besarnya pertambahan bobot badan yang diperoleh. Semakin tinggi tingkat konsumsi 
ransum semakin tinggi pula pertambahan berat badan yang dihasilkan, demikian pula sebaliknya. Lebih lanjut, menurut Wahyu (1997) pertambahan bobot badan juga dapat disebabkan oleh retensi protein yang tinggi sebagai dampak fermentasi. Terdapat hubungan nyata antara retensi nitrogen dengan pertambahan berat badan.

Pemanfaatan ampas sagu sebagai alternatif pakan ternak dapat dilakukan di Papua. Hal ini karena Papua mempunyai kawasan lahan sagu terbesar di Indonesia dengan tingat produksi tinggi (Dewi et al., 2016). Menurut Pamungkas (2011) dan Fitrihidajati et al. (2015) bahan alternatif pakan dapat ditingkatkan kualitasnya dengan cara dilakukan fermentasi. Dengan demikian, alternative sagu cukup menjanjikan untuk dimanfaatkan salah satu pakan ternak alternatif ayam kampung dan potensinya pada berbagai jenis hewan ternak lainnya.

\section{KESIMPULAN}

Hasil analisis kimia ampas sagu menunjukkan bahwa terjadi perubahan nilai gizi sebelum dan setelah fermentasi. Perlakuan fermentasi mampu meningkatkan protein kasar, serat kasar, dan lemak kasar ampas sagu. FAS yang diujikan pada ayam kampung jantan berpengaruh terhadap peningkatan pertumbuhan bobot ayam kampung jantan. Perlakuan terbaik untuk peningkatan pertumbuhan ayam kampung jantan adalah P1, yakni campuran antara pakan basal (PB) 96\% dan FAS 4\%, yang mampu meningkatkan hingga $17,8 \%$. Ampas sagu hasil sisa produksi pengolahan pati dapat dimanfaatkan sebagai sumber pakan alternative ternak ayam.

\section{DAFTAR PUSTAKA}

Buckle, K.A., R.A. Edwards, G.H. Fleet and M. Wooton. 1987. Ilmu Pangan. UI-Press, Jakarta.

Dewi, R.K., M.H. Bintoro, dan Sudradjat. 2016. Karakter Morfologi dan Potensi Produksi Beberapa Aksesi Sagu (Metroxylon spp.) di Kabupaten Sorong Selatan, Papua Barat. $J$. Agron. Indonesia. 44(1): 91-97.
Ehara, H., S. Susanto, C. Mizota, S. Hirose, and T. Matsuno. 2000. Sago palm (Metroxylon $\mathrm{Sagu}$, Arecaceae) production in the Eastern Archipelago of Indonesia: Variation in morphological characteristics and pith drymatter yield. Economic Botany. 54(2): 197 206.

Fardiaz, S. 1998. Fisiologi Fermentasi. PAU. Pangan dan Gizi Institut Pertanian Bogor.

Fitrihidajati, H., E. Ratnasari, Isnawati, dan G. Soeparno. 2015. Kualitas hasil fermentasi pada pembuatan pakan ternak ruminansia berbahan baku eceng gondok (Eichornia crassipes). Biosaintifika. 7(1): 62-67.

Flach, M., and D.L. Schuiling. 1989. Revival of an ancient starch crop: a review of the agronomy of sago palm. Agroforestry Syst. 7: 259-281.

Heinz, V., R. Buckow, and D. Knorr. 2005. Catalytic activity of amylase from barley in different pressure/temperature domains. Biotechnol. Prog. 21(6): 1632-1638.

Karim, A.A., A. Pei-Lang Tie, D.M.A. Manan, and I.S.M. Zaidul. 2008. Starch from the sago (Metroxylon sagu) palm tree-properties, prospects, and challenges as a new industrial source for food and other eses. Comprehensive Reviews in food sciences and food safety. 7(3): 215-228.

Kompiang, I.D, Zainuddin, D, Supriyati. 1995. Pemanfaatan limbah sagu sebagai ransum ternak ayam. Kumpulan Hasil-hasil Penelitian. Balai Penelitian Ternak, Ciawi, Bogor.

Kusuma, P.T.W.W., N. Indrianti, dan R. Ekafitri. 2013. Potensi tanaman sagu (Metroxylon sagu) dalam mendukung ketahanan pangan nasional. Pangan. 22(1): 61-76.

Lay, A.F., dan M. Patrik. 2010. Optimalisasi pengolahan sagu (Metroxylon sp) menjadi biofuel. Warta Penelitian dan Pengembangan Tanaman.

Leeson, S. and J. D. Summers. 2001. Nutrition of the chicken. $4^{\text {th }}$ Ed.University Books. Guelp, Ontario, Canada. 
Lerch. 1978. Amino acid sequence of tyrosinase from Neuspora crassa. Proc Natl Acad Sci. 75(8): 3635-3639.

Marathe, S., Y. G.Yu, G.E. Turner, C. Palmier and R.L. Weiss. 1998. Multiple forms of Arginine and Metionine from single locus in Neurospora crassa. Journal of Biological Chemistry. 273:29776-29785.

Mathur, P.N., KW. Riley, V.R. Rao, and M. Zhou. 1998. Conservation and sustainable use of sago (Metroxylon sago) genetic resources. In: C Jose, A Rasyad, editors. Proceedings of the Sixth International Sago Symposium. Pekanbaru, Riau, Indonesia: Riau Univ. Training Centre. pp: 1-6.

McDonald, P.R, R.A. Edward and J. F. P.D Greenhalgh, 1982. Animal Nutrition. $3^{\text {th }}$ Ed. Longman Inc., New York, USA.

McNab, R. and L. A. Glover. 1991. Inhibition of Neuspora crassa cytosolic chitinase by allosamidin FEMS Microbiology Letters, 82:79-82.

Mubekti. 2013. Spatial statistics for estimating sago stock in West Papua, Indonesia. Jurnal Teknologi Lingkungan. 14(2): 95-100.

Palmier, C. 1999. Purification and Characterization amino acid from Neurospora crassa. Thesis (PhD) University of California Los Angeles.

Pamungkas, W. 2011. Teknologi fermentasi, alternatif solusi dalam upaya pemanfaatan bahan pakan lokal. 6(1): 43-48.

Rahayu, Y., Fitmawati, and Herman. 2013. Analisis keanekaragaman sagu (Metroxylon sagu Rottb.) pada tiga tipe habitat di Pulau Padang Kepulauan Meranti. Biosaintifika. 5(1): 16-24.

Rhodes, W. G., R. A. Lindberg and H. Drucker. 1983. Purification and characterization of an extracellular acidprotease from Neuspora crassa. Biochemistry and Biophisics. 223:514-520.
Romero, M. D., J. Aguado, L. Gonzalez and M. Ladero. 1999. Cellulase production ba Neurospora crassa on wheat straw. Enzyme and Microbial Technology, 25:244-250.

Tsai, H and S.R. Suskind. 1972. Enzymic properties of a mutant tryptophan synthase from Neurospora crassa. Biochimica et Biophysica Acta (BBA)-Enzymology. 284: 324-340.

Usman, dan S. Tirajoh. 2018. Potensi dan pemanfaatan ampas sagu (Metroxylon sp.) sebagai pakan ternak ruminansi. Prosiding Seminar Nasional. Fakultas MIFA, Universitas Cederwasih, Papua.

Wahyu, J. 1997. Ilmu Nutrisi Unggas. Gadjah Mada University Press. Yogyakarta.

Widjono, A., R. Aser, dan Amisnaipa. 2000. Identifikasi, karakterisasi, dan koleksi jenisjenis sagu. Prosiding Seminar Hasil-Hasil Sistem Usaha Tani Papua. Pusat Sosial Ekonomi Pertanian, Bogor. Hlm: 9-16.

Wolf, E.C. and R.L.Weiss. 1990. Acetylglutamat kinase by Neurospora crassa. Journal of Biological Chemistry. 225: 9189-9195. 